\title{
I DIE A LITTLE
}

\section{Parting is such sweet sorrow.}

\section{BY BO BALDER}

\section{I} trudge back to the plass bubble separating us from the rest ing planet after weeding my row of beans. They're just-in-case beans, if we're stuck here for another six months. I take my place at the outer point of the bubble. That's where the kids come to visit, if they come.

It's a dreary, rainy day outside, with low visibility. Probably that's why it's so quiet there. Usually we're fighting about the best place to wave and make faces at our kids. I've been trying to teach the others sign language but most of the parents are too impatient. I don't get it. You've got months in which you could learn to communicate with your kid, whom you'll never see again when we humans leave the planet. I'd know what I'd do.

They've put us inside the bubble, much like the one we ourselves had put over our settlement. The difference is there are no exits. It's a prison. We can look out and breathe freely, but that's it. We can only wait until the ships pick us up to take us away. The Ha Chai, an approximation of the sound they make if they squeeze their spongy protuberances, like a sneeze, want us gone.

And who can blame them? We set down here blithely, excited at having found a human-compatible planet, and we didn't look closely enough to see who was here before us. As in sentient beings, I mean. But they were very polite about it. Civilized. Gave us the choice. Join or leave.

And I wouldn't care about any of it, although spending another seven years in cryosleep at my age won't be fun, if Lawrentz hadn't decided to join. I mean, how could he? Leave his ageing mother and join a people of asymmetrical, frankly unappealingly slimy, fungal colonies?

I just don't understand. He was born on Earth, for god's sake. Yes, it's sad the colony failed, but I don't feel guilty about it. We couldn't have known that those lovely coral castles were colonies of people, mobile $\rightarrow$ NATURE.COM Follow Futures: @ @NatureFutures f go.nature.com $/ \mathrm{mtoodm}$ sponges in their youthful forms. We absolutely couldn't have. And I think we were reasonable, too.
We only wanted one large island; we would have left them the rest of the world. More than fair.

Lawrentz doesn't agree. Most of the kids don't. They feel that the sneezers have every right to deny us a crumb of their cake. I've told him stories about refugees back on Earth, that we owe homeless and landless people support. In response he showed me old videos about us refugees being cooped up in miserable tent cities, drowning, walls being built. The world we left for a reason.

While here, on this planet, there is an endless slow vegetable dance of harmony and happiness. The joy of changing seasons, the taste of the roe in the water. He says.

I sink down in one of the old plastic garden chairs we've set out, prepared to wait a while. All day, actually. But the form that looms up out of the mist is Lawrentz. His walk is still his walk. His face is still there, although it's turned a mottled purple instead of its regular brown. His hair and ears are lumpy growths now.

He signs hello to me, with arms that are longer and thinner and hands that have fused together. I can recognize the signs only because I know him, I know his body language, his expressions. But he's here. We can talk. I'm so grateful that I taught him sign language, not just so he could talk with my dad but also to have something private between us.

I wish we could talk about anything but the coming separation. But somehow we never do. I want to talk to him about his dreams for the future, which college he should go to. Is there a girl or boy he likes? But I can’t ask him these things because they're all moot. He's going to live on this horrible planet and if he likes anyone they'll be a sexless sponge. That would be great, actually. But there are no other choices. He has no option but do for a living what the other sponges do. They eat algae until they're fully grown and then they root in the earth, forming a communal entity like coral. That's his future.

He's a boy, a young man, he's supposed to be leaving home. What should he say?

I'm not saying please come back. Because it's irreversible.

I don't ask, how could you leave me? Because he's supposed to. Children leave.

I don't say, I'll miss you so much. Because I already do. I miss the old him.

Lawrentz starts signing. Hand pointed at himself, hands crossed over his heart, fingers pointing at me. "I love you," he says.

"I love you too," I reply.

"I miss you," he says. I’ve always loved that touch on the dimple below the lips.

"The ship is coming," he says. "Tonight."

I wonder how spongy corals know this before we do with our sophisticated instruments.

"Mum, please," he says. His spongy face can't show emotion, but I've 20 years of entreaty in my memory. "Please stay here with me. You can still change over. It's a beautiful thing to be part of the coral. Mum, we sing together all the time."

I break. I sign him I love him. But I also sign him no. I can't give up my humanity. I just can't. He's going to have to do this alone.

And then I realize he's not leaving me. I'm leaving him.

And I die a little.

Bo Balder is the first Dutch author to be published in Fantasy \& Science Fiction. Her short fiction has appeared in Futuristica Volume 1 and other places. Her SF novel The Wan was published by Pink Narcissus Press in 2016. 